right eye vision $=6 / 6$, left eye vision $=6 / 6$. There were fine dustlike vitreous opacities in the right eye. The disc presented the appearance of a subsiding neuritis with commencing atrophy, the arteries were narrow and thread-like, the peripapillary retina a dull grey. The haemorrhages had disappeared.

\title{
REFERENCES
}

Cruickshank and Wright.-Filariasis in Cochin. Ind.Jl. of Med. Res., Vol. I, No. 4, 1914.

Brug.-Filaria Malayi N. Sp. Parasitic in Man in the Malay Archipelago. Trans. Far. E. Cong. Trop. Med., Vol. III, 1927.

Mapleston.-A re-description of Wuchereria Bancrofti (Cobbold, 1877) with special reference to the tail in the male. Ind. Jl. Med. Res., Vol. XVI, p. 683, 1929.

Iyengar.-Filariasis in North Travancore. Ind. Jl. Med. Res., Vol. XX, October, 1932.

Filariasis in Trivandrum. Ind. Jl. Med. Res., Vol. XX, April, 1933.

\section{CATHOLYSIS AS A NEW TECHNIQUE FOR OPERATIVE CLOSURE OF HOLES IN THE RETINA AND FOR TREATMENT OF ITS DETACHMENT}

\author{
BY \\ A. VogT \\ $z \ddot{U} \mathbf{R I C H}$
}

At the meeting of the Swiss Ophthalmological Society, May 4, 1934, Vogt reported for the first time on his new method of "catholysis." The apparatus generally used for electrolysis of the lashes can be employed. The anode is placed on the surface of the eye. The cathode is a very fine needle. After removal of the conjunctiva the spot is marked on the sclera with Indian ink. The needle cathode is passed through the sclera, deep enough to reach the detached retina. The application is very short. Galvanic current of 0.5 to 1 milliampères is used. The hole and its boundaries must be touched.

The method shows the following advantages in comparison with the galvano-cautery, the benzene-cautery and the caustic potash :-

1. Catholysis does the least damage. Cauterization produces temperatures of $500^{\circ} \mathrm{C}$. to $1,000^{\circ} \mathrm{C}$., caustic potash destroys the tissue to an uncontrollable extent; diathermy with 50 to 100 milliampères causes burns. The diathermic needle also pierces the detached retina in a dangerous and useless manner. The catholysis, 
on the contrary, introduces only very small quantities of energy into the eye ( 0.5 to 1 milliamperres). Thus the method is the most adequate to treat the delicate retina.

2. The other methods often produced scar membranes and secondary holes, opacities of the lens, optic neuritis. Late haemorrhages sometimes have occurred. These complications have never arisen after the new operation.

3. Only very small quantities of the vitreous are lost, even when the sclera is punctured frequently at one operation, which therefore need not be interrupted.

4. The needle can be passed into the eye as often as we want without danger, provided that only 0.5 to 1 milliampères are used and that the application lasts less than a second each time. Very large holes and multiple holes can, therefore, be treated in one operation. Exact dosage is possible.

5 . The method was introduced by Vogt primarily because the cathode produces bubbles of hydrogen in the eye, at its point as well as along its whole length. These bubbles can easily be seen with the ophthalmoscope and allow determination of the topographical relations between the hole and the first puncture during the operation. We are able to make a preliminary puncture for orientation, and after ohpthalmoscopic control and correction of the puncture position on the sclera, to close the hole with a series of 5 to 20 or more punctures.

6. The method is very simple, harmless and painless. The scars are much more delicate than those following other methods. The operation can be finished in 5 to 10 minutes provided that the eye is prepared the day before and that care is taken to have a perfectly transparent cornea before and during the operation.

7. The results of the new method have been, up to the present, excellent. It was successful in cases of very old detachment, of very large holes and even in aged patients.

It must not be forgotten to put the anode on the bulb before the cathode pierces the sclera.

In 1893 Schoeler and Abadie tried electrolysis in cases of detachment apparently without permanent success, because they did not "aim" at the hole. Also the dosage was unsuitable. Nevertheless, recognition must be accorded to them for the introduction of electrolysis in the treatment of detachment. In 1894 Schoeler and Albran reported the results of histological investigations and demonstrated the delicacy of scarring. However, they, as well as Abadie, used the anode. von Szily and Machemer tried superficial electrolysis; they described the results of perforating electrolysis with the anode on healthy mammalian eyes and on a human eye without detachment. The use of the cathode was introduced by Vogt. 